pital, at Cheedle, accommodates about eighty patients of the middle class; and the other, the Coton Hill Institution, at Stafford, a somewhat larger number, in a style with which, as to whether as to apartments, furniture, attendance, or facilities for rational discussion, any reasonable insane Englishman of those classes ought to be perfectly satisfied. Belonging to the same order of institutions is one possessing historical fame and interest, which yet retains its early popularity, as well as its excellent reputation among medical men. The York Retreat, founded by the Society of Friends at the close of the last century, and hallowed in the memory of every one who appreciates the spirit of beneficence which originated it and has ever since pervaded its halls, still pursues its sacred mission of removing and relieving mental disease. Nowhere did I observe clearer evidence of intelligent and conscientious fulfilment of the humane purposes of all such institutions. The older sections of the building were being gradually replaced by new constructions, which conform interiorly to the present standard of advancement; and as for that personal devotion of the chief officers, on which the welfare of patients must mainly depend, it was sufficiently apparent that the genius and the earnestness of Jake still abide anong his successors.

"Bethlehem and St. Luke's Hospitals still continue to be occupied as receptacles for the insane. Any term implying a more enlightened humanity than this, would seem an insult to English intelligence and philanthropy. The Commissioners in Lunacy, and other friends of the insane, have long sought to induce the removal of these institutions, from the densely built districts of London to the open country, but hitherto without success. The only prospect now presented from their windows are masses of closely packed city houses, and the usual scenes of city streets, while the range for outdoor exercise is restricted to the narrow limits of small and gloomy enclosures. Of course the great value of the sites now occupied by these buildings would enable the governors, in conjunction vith their permanent funds, to provide in each case a model establishment, in the most eligible suburban positions. Each institution, however, possesses an income sufficiently generous to justify its governors in indulging the good old English trait of obstinate adherence to their own will, and it being their will to retain their institutions where they are-for the reason that they have existed where they stand from time immemorial; and as this reason gathers strength daily, there these hospitals will probably remain until the New Zealand artist, whose eventual arrival Mr. Macaulay has predicted, takes his seat on the 'crumbling pier of London Bridge,' to begin his sketch of the 'ancient ruins of St. Paul's Church.'

"If nothing else shall then be left of the present unornamented glories of the great city, Bethlehem and St. Luke's will doubtless continue to stand, to prove that nothing can so long resist the tooth of time, or the encroachment of reform, as the conceit and prejudice of the governors of a well-endowed charity."-Dr. Tilden Brown, Physiciun to the Bloomingdale Asylum, New York (American Journal of Insanity, Oct. 1863).

\title{
Dr. Conolly on the Character of Hamlet.*
}

"A writer, who has made mental disease his peculiar study, and who ranks high among thuse who deal with it practically and theoretically, deserves attention when he takes the psychology of Hamlet or Lear for his theme. His opinion carries the greater weight when, with his proper science, he

* 'A Study of Hamlet,' by John Conolly, M.D., D.C.L., Fellow of the Royal College of Physicians. Fep. 8vo. London: Moxon, 1863. 
combines a highly cultivated taste and literary accomplishments. On each of these accounts Dr. Conolly has a claim upon our notice when he writes of madness as delineated or illustrated by Shakspeare.

"Of all the dramas of our prince of poets, Hamlet is at once the most popular, and the most perplexing as regards its inner and its ultimate meanings. It is always acceptable on the stage, whether the actor struts his hour in a barn or in a Theatre Royal. Mediocre, or even bad acting. scarcely abates the interests it aw akens; the most consummate of performers leaves something incomplete in the principal character; and we have constantly to desire better representatives of the King, Polonius, Horatio, or the Grave-diggers. To the reader, Hamlet is generally the most attractive of Shakspeare's plays. John Kemble observed that, in every copy of Shakspeare's works, it appeared that Hamlel had been the play most read; and Gervinus remarks, that wherever the name of Shakspeare is mentioned, the play of Hamlet comes first to remembrance. Of the many maxims that have become proverbial among us in daily life or common speech, through the medium of the poet, no $f \in w$ are derived from this drama alone. It is, of all his writings, the best known to the comparatively ignorant, the most familiar to the well-informed. And yet, although Hamlet pervades the surface of our thoughts and associations, there is almost infinite disagreement about the character itself and the author's intention in the play generally. In nothing do doctors differ more than in their expositions of this drama. By Voltaire it is regarded as the most Goethe and extravagant of the productions of ce bouffon de Shakspeare-by Ulrici, as the most profound specimen of his philosophy. It has been debated whether the author did not materially alter his design in successive drafts or editions of Humlet. French critics, and actors in general, believe-we must say, on slender evidence-that the Queen-mother was an accomplice in the murder of her first husband. 'Then, as regards Polonius, was he a fool positive, as it too of ten pleases the actor to represent him, or had age impaired his memory and natural shrewdness? Tieck broaches the monstrous and, indeed, almost profane notion that Ophelia was Hamlet's mistress! Garrick banished the grave-diggers from his acting copy - an absurdity which the German theatre still retains. The great problem of all, however, is the one examined by Dr. Conolly in the little volume before us-was Hamlet mad from the beginning of the play, or mad only at certain crises of the action; or did be feign madness, like Ulysses or Brutus, for the furtherance of his own designs?

"We shall not attempt tanlus componere lites. It is hopeless to discuss within our limits a question so long, and so variously agitated. We shall render $\mathrm{Dr}$. Conolly and our readers better service by abridging his argument, and leaving the doubt, as it has always been, and may probably always be, unresolved. Dr. Conolly has furnished us with a most careful analysis of the drama, and supported his opinion, that Hamlet was actually insane from the first, by many striking remarks, and many pertinent illustrations. In the story which furnished Shakspeare with his plot, Hamlet feigns madness; but then, on the other hand, he avenges his father promptly and properly, survives the deaths of his uncle and his guilty mother, und is altogether as different a person from the philosophical prince as Regnar-Lodbrog was from Tycho Brahe. No conclusions, accordingly, as to Hamlet's sanity or insanity in the play, can be drawn from the original legend. The Hamlet of Saxo.Grammaticus had in him the soul of Nero, as his actions proved; the Hamlet of the play could contemplate a brave revenge as possible to him, and even incumbent upon him, but he was as incapable of executing it as of forgiving his uncle-father.

"To readers, spectators, and actors alike, if not wedded incurably to 
stage traditions. Dr. Conolly's speculations may be very valuable. The play which Shakspeare wrote is in manv respects a very different matter from that which Garrick, Kemble, and the Keans represented. The length of the drama imposes on the performers the necessity of curtailments, and these are often the more injurious to the whole, because, in compliance with common, but evil custom, the subsidiary characters are cut down remorselessly, in order that the principal one may stand out in bolder relief. Thus, the speech which records the King's futile attempt to pray, and the dialogue that contains the key to the proper defects of Polonius, are both struck out; and so the Lord Chamberlain is left little better than a meddling and mischievous droll, and the King a drunken blockhead, whom it is impossible to conceive of as capable of wooing or winning even a fickle and foolish woman. We should much like to see a prompter's copy of Hamlet as it wos performed by Burbadge. We suspect that the 'cuttings' in it were much less pernicious to the play than our present excisions. In those early days, and in great Eliza's golden prime, the heathenish custom did not prevail of marring the effect of tragedy by farcical preludes or sequels, and consequently it. was not so impossible to play out the play as it is at the present hour. A farce, or any performance, after the curtain has dropped on the Court of Denmark, seems to us little less out of place than was the song of 'Possum up a gum-tree,' demanded by a negro pit of a sable Prince of Denmark, immediately on the heels of the famous soliloquy on suicide and dreams after death.

"Hamlet, in Dr. Conolly's view, is always insanurient; that is to say, he is of a temperament in which madness lies very near the surface, and which some violent shock, or unlooked-for calamity, is certain to develope into disease. Under favorable circumstances, continued through a long series of years, if not through an entire life, this morbid propensity might have been curbed, until the relaxation and palliatives of age had blunted the edge of passion, or stilled the activity of the reflective powers. But this boon was not accorded to the sad and speculative Hamlet. Before he is thirty years of age, his moral being, and the world of his affections, sustain a violent wrench. The studious and meditative man, whose delights hitherto have been in speculation, is called upon by strong suspicion at first, and next by an awful revelation from the tomb, to prompt action, and the necessity to act is to him as alien and unwelcome as the sound of the trumpet and the signal for battle would be to a hermit in his care, or to a student in his cell. Hamlet, at need, and under instantaneous pressure, allowing no time for thought, can quit himself bravely; but allow him only a few minutes for contemplating the event, and his being is unnerved, and the admitted duty becomes an impossibility.

"We need not go very far for illustrations of such a character, though we may not find its parallel or counterpart. The most profound thinker, by the admission of his own contemporaries, in the present century, was Samuel Taylor Coleridge. If not a poet of the highest order, his poetical powers and instincts were of the first quality. In philosophy, it is difficult to say what it was that he wanted, and yet the want is perceptible in all he wrote. It was not subtlety of thought, nor impatience of continuous reasoning. In those respects he had no superior, not even in Immanuel Kant. It was not the power of clothing high speculation in befitting words that he lacked, for Coleridge occasionally writes with the vigour and lucidity of Plato or Descartes. Neither was it learning that he fell short in; for although he may not have devoured books like Robert Southey, he was one of the deepest and most various readers, and one also of the hardest students of his day. Of his eloquence in discourse it is superfluous to speak. He was at once the Aristotle and the Chrysostom of monologue, following the 
severest trains of thought, and adorning them with the most apt and felicitous illustrations that an active memory or a fertile imagination could supply. And yet, if what he did in psychology or poetry be compared with what he was capable of doing, the intellectual no less than the practical life of Coleridge must be pronounced a blank. His name is not inscribed on the title-page of any work that will live for ever. He realised no one of his mighty projects; he founded no school, he inaugurated no system of philosophy; he did not even reconcile, as he once promised to do, the discordant schools or systems of the past with one another. He lacked active vigour; he suffered from infirmity of purpose; he was for ever dallying with the event, as Hainlet dallied with the duty imposed upon him by the sin and calamity of his house.

"Dr. Conolly has, in our opinion, not sufficiently insisted upon the wholesome restraint which the elder Hamlet must have exercised on his son-a restraint that became distinctly conscious to him only when it was removed for ever. With wondrous art Shakspeare has disclosed to us the character of the father through the words of the son. An inferior dramatist would have told us, by these or some other organ, what manner of man the buried Majesty of Denmark was-Shakspeare has made us feel what he had been to his son, his queen, his courtiers, and his friends. Much in the son's disclosures may be set down to the account of natural affection; much to deeply-rooted reverence and admiration. But the son's expressions of love and respect for the father, of indignation at his mother's hasty and indecent second marriage, of his abhorrence for his uncle even before he is aware of the depth of his uncle's guilt, imply, in our opinion, more than the several or combined sentiments of love, indignation, and abhorrence. 'They lead to the inference that the one stay on which Hamlet had rested, the one barrier between mental sanity and incipient or comp!ete disease of the wit, was broken and removed by the elder Hamlet's death. He was, if we may estimate his character from what his son and Horatio impart, a man of great sobriety of mind and of much vigour in action - a man, like Tennyson's King Arthur, to be feared as well as loved-one fitted to bear a kingdom's weight, a bright example of household governance, grave, true, and yet tender. Under such guidance, the very dissimilar nature of the son was kept under wholesome restraint, and yet its strong affections were not nipped in the bud. To such a son, in whom the theorique in life far outweighed the practique, such a father was a pole-star, and when its light was withdrawn, suddenly and for ever, the chart and rudder of the son's after life were rendered nearly unserviceable. That Hamlet needed such an outward monitor and guide is, perhaps, implied in his choice of the calm, cheerful, and independent Horatio for his friend and confidant. They are, in all respects, except common love and reverence, the opposites of each other. Inferior to his princely friend in intellect, Horatio is superior to him in will. He cannot, indeed, supply the void which death has made, but he can at least serve as an occasional prop to the vacillating temper of Hamlet. He is no broken reed like Rosencranz and Guildenstern; no hope of preferment will turn Horatio into a tool of Claudius or a flatterer of Gertrude.

"Dr. Conolly's remarks on the preparation for Hamlet's appearance, and for the series of woes impending over the Royal House of Denmark, are all worth the reader's attention. In no one of his plays has Shakspeare so carefully sounded the notes of preparation for a tragic issue as in this one. We are immediately warned of Lear's folly, of Macbeth's ambition and temptation, of Iago's malevolence, of the Second Richard's levity, of the arrogance of Coriolanus, of Wolsey's pride, and the envy of the nobles towards that haughty priest. But, in Hamlet, the inaugu- 
ration of the secret to be revealed, the introduction of the awful shadow that is creeping over the halls of Elsinore, are evolved as carefully as in that august and terrible preface to the Eumenides, in which the priestess discerns the Furies and their victim slumbering in the portals of the Delphic Temple.

"' 'he circumstances that mark Hamlet's first entrance are traced with great skill. The King himself directs our attention to the mingled joy and sorrow of what we may presume to have been his first levee. He glosses over the indecorum of his marriage with his brother's wife by an allusion to 'mirth in funeral and dirge in marriage.' He exercises publicly, for the first time since his accession, Royal functions. He sends ofl the ambassadors to 'Old Norway ; he grants the suit of Laertes with gracious reference to Polonius. So far he acts as a monarch. Next, but with less success, be assumes the part of a futher, and attempts to divert Hamlet from his melancholy reverie. We are left to imagine the feelings of the bystanders. The veteran courtier, Polonius, has transferred his allegiance from one brother to another, without scruple or surprise. No remembrance of his former patron and friend ruffles his official calm. It is enough for him that be still wields the rod of office. Laertes, bent on his return to France, recks not of other 'delight or dole.' We may imagine Gertrude to have been less easy in her bridal robes; but her anxiety is diverted from the opinion of the Court to the worn and abstracted bearing of her son. It is an everpresent dread with her that the o'er-hasty marriage has aggravated the bitterness of his father's death.

"But the central figure of this group-is it that of a sane or an insane person? Dr. Conolly says, that as soon as the levée breaks up, 'we learn the actual mental state of the unhappy prince.' In his reply to the cold arguments of his uncle, and the earnest pleadings of his mother, he has replied, ' in terms denoting a mind not only occupied but disturbed with' grief. But he is át length alone, and 'even now, unconscious of what he is soon to know, we perceive that his mind is a very whirlpool of violent and miserable thoughts; that suggestions of self-destruction already lie and heave among them; that he feels the sum of his misery even now too inuch for him ; and that the chief part is his mother's marriage to his hated uncle.' We now pass to Hamlet's demeanour and language immediately after the grave has disclosed its terrible secret, and the dead has imposed on him the active duty of revenge. In the 'resolve to remodel all the manner of his life, to alter every habit, to sacrifice every customary pleasure,' no less than in the wild and parting words with which he accosts Horatio and Marcellus, no less than in the jesting phrase, 'boy,' and 'true-penny,' and 'old mole,' Dr. Conolly detects usual features of wit diseased. But the remarks which follow yet more forcibly explain his thenry of Hamlet's character :-

"The injunction to his friends to abstain from all indications of being able to account for his conduct, however strange his conduct may hereafter appear, has been generally adduced as indubitably proving that all Hamlet's subsequent eccentricity is to be interpreted as mere acting. It is as generally overlooked that the interpretation can scarcely extend to the eccentricity previously manifested, or explain his conduct and language before he had heard anything of the appearance of his father's ghost. Among his confused resolves, that of feigning madness seems suddenly to have sug. gested itself, either as subsidiary to some equally obscure plan of revenging his father's death, or merely to account for the wild words he had been uttering. The suggestion might have arisen in his mind in the short interval between the departure of the ghost from his sight and his rejoining his friends. We shall find that it is never acted upon as a part of a consistent plan, but recurs to him now and then, and fitfully, and is at such times 
acted upon, not as a deliberately planned conduct, but as something lost sight of amidst the real tumult of a mind unfeignedly disordered. A critic of the highest class (Coleridge), and who appears to have accepted the simulation of Hamlet's madness without question, has yet been constrained, by a consideration of these and other wild passages, to say that 'Hamlet's wildness is but half false-he plays that subtle trick of pretending to act only when he is very near really being what he acts.'

"The demands of the stage add considerably to the difficulties inherent. in this play. The compression of the action into little more than three hours hurries on its several stages, and often creates improbabilities which do not, or need not, trouble us in reading it. For the reader, an uncertain period of days, or even months, may elapse between the end of the first and the beginning of the second act, and there may be ample time for melancholy to convert Hamlet into the forlorn wretch who alarms Ophelia, 'sewing in her chamber.' His behaviour on that occasion is one among the most convincing proofs, in Dr. Conolly's opinion, of the reality, and indeed of the depth, of Hamlet's madness. He shrewdly remarks that-

"If we admit that the disordered dress might have been studied, and that the unbraced doublet, the fouled stockings, ungartered and down-gyved, tere merely disarranged for the purpose of acting an unmeaning or a cruel part, we cannot readily say the same of the pale and piteous look-

\section{As if he had been loosed out of hell}

To speak of horrors.

“ ' These descriptive particulars cannot have been perversely designed br Shakspeare to pourtray the masquerading of a princely gentleman, oppressed with sorrow, for the abject purpose of exhibiting himself, careless of distressing the object of his deepest affections.'

"He recurs to this argument after Hamlet's next interview, 'less tender and yet more disturbing,' with Ophelia, in which be agrees nearly with Claudius-'Love! his affections do not that way tend.' The longer the interval between Hamlet's vision of the ghost and the progress of the action, the deeper becomes his distrust of the revelation, the more infirm his purpose of revenge, and the more surely seated the disease of his mind. Like other critics, Dr. Conolly admits that Hamlet has paroxysms of madness, amounting at times to acute mania; he differs from them only in denying that he is ever really sane, until indeed the closing scene. The better part of Hamlet survives all his mental discomposures. Death, stronger than madness, calms, corroborates, and heals his perturbed soul, and in a moment enables him to fulfil the hest which in weeks or months of irresolution he had dallied with and deferred. With death in his veins, and approaching his heart, he gains strength to punish the guilty, to provide for his own vindication, and to name the successor to the throne.

"We have given a slight sketch, but not pronounced an opinion, of $\mathrm{Dr}$. Conolly's theory. It may persuade some and offend others; but whether he gains or fails of gaining assent, his little volume affords an admirable commentary on this the most psychological of Shakspeare's plays, and may be studied with equal profit by readers, spectators, and actors." - The Salurday Reoieso, July 4th, 1863.

\section{Mr. Paget on the Mental and Material Rewards of the Profession of Medicine.}

"The burden of my addess is, work, life-long work. And so it is, and so It must be; there is no success without it-no happiness without it. 